\title{
Complement activation and complement control proteins in acute pancreatitis
}

\author{
J T WHICHER,* M P BARNES, A BROWN, M J COOPER, \\ R READ, G WALTERS, and R C N WILLIAMSON \\ From the Departments of Chemical Pathology and Surgery, Bristol Royal Infirmary, Bristol
}

SUMmaRY Serum levels of the complement proteins C3, C4, C1 inhibitor (C1 INH), factor I ( $\mathrm{C} 3 \mathrm{~b}$ inactivator) and factor $\mathrm{H}(\mathrm{BIH})$ and plasma levels of cleavage products of $\mathrm{C} 3(\mathrm{C} 3 \mathrm{c})$ and factor B were measured in 26 patients with acute pancreatitis. Breakdown of C3 occurred in 19 patients, as shown by a reduction in $\mathrm{C} 3$ level and the presence of $\mathrm{C} 3 \mathrm{c}$. $\mathrm{C} 4$ levels, however, did not fall and factor B breakdown products were not detected, thus suggesting that enzymatic cleavage of C3 occurred without significant involvement of either the early classical pathway or the alternative pathway. $\mathrm{C} 1 \mathrm{INH}$ and factor $\mathrm{H}$ both showed increases, presumably reflecting an acute phase response. Factor I showed an initial fall followed by a rise. There was no correlation between the presence or extent of $\mathrm{C} 3$ breakdown and the clinical condition of the patients. It is concluded that $\mathrm{C} 3$ cleavage in pancreatitis probably results from tryptic activity and that the measurement of complement components has no part to play in the management of the disease.

In acute pancreatitis activated proteases are released into the local glandular structure. Their role in the pathogenesis of the disease, however, is controversial. Normally, the presence of circulating protease inhibitors ensures that released proteolytic enzymes are quickly complexed but, in dogs with acute pancreatitis induced by a closed duodenal loop, when the inhibitors become saturated active trypsin becomes detectable in the ascitic fluid. This may then activate other proteases ${ }^{12}$ such as plasmin, Hagemann factor, and complement, which mediate an inflammatory reaction.

Interest has centred on the complement system as the mediator in acute pancreatitis. Not only are its components, in particular $\mathrm{C} 3$ and $\mathrm{C} 5$, susceptible to attack by trypsin ${ }^{3-6}$ but in human and experimental pancreatitis plasma $\mathrm{C} 3$ levels have been found to be depressed, sometimes associated with the presence of circulating $\mathrm{C} 3$ breakdown products.$^{7-11}$ It has also been suggested that the magnitude and duration of such depression in patients gives an indication of the prognosis. $^{8}$

We have observed, however, that serum levels of

\footnotetext{
* Address for réquests for reprints: Dr J T Whicher, Department of Chemical Pathology, Bristol Royal Infirmary, Bristol BS2 8HW.

Received for publication 1 February 1982
}

C3 may actually rise in some patients with acute pancreatitis, due to an acute phase response, and therefore we felt it necessary to examine in more detail the relationship between changes in complement components and other factors. In addition to studying $\mathrm{C} 3$ and $\mathrm{C} 4$ we have also studied other complement proteins, including the inhibitors which modulate complement turnover, and also the alternative pathway protease, factor $B$.

\section{Methods}

\section{PATIENTS}

Twenty-six patients admitted to the Bristol and Southmead Health Districts between December 1978 and August 1979 with acute pancreatitis were entered into the study. The clinical diagnosis was confirmed by serum amylase levels exceeding 1000 Sömogyi units or 2000 IU(Phadebas). Venous blood collected on admission and daily for the next three to four days was analysed for $\mathrm{C} 3, \mathrm{C} 4, \mathrm{C} 3$ conversion products, factor $\mathrm{B}$ conversion products, $\mathrm{C} 1$ inhibitor (C1INH), factor I, and factor $\mathrm{H}$.

Blood for complement estimation was collected into ethylene diamine tetra-acetate (EDTA) tubes, (Labco, Marlow, UK) after discarding the first few 
millilitres of the sample. It was promptly transported to the laboratory for separation of the plasma, which was either examined immediately or stored at $-70^{\circ} \mathrm{C}$. These precautions eliminate in vitro complement breakdown. ${ }^{12}$

C3 levels were measured by laser nephelometry using a Hyland PDQ laser nephelometer (Hyland, Costa Mesa, California, USA). C1INH, factor I, and factor $\mathrm{H}$ were measured by electroimmunodiffusion. ${ }^{11}$ Antisera to $\mathrm{C} 3$, to factor $\mathrm{B}$ and to C1INH were obtained from Atlantic Antibodies (Westbrook, Maine, USA) and to factor I and factor $\mathrm{H}$ from Seward Laboratories (London, UK). C3 and factor B breakdown products were detected by immunofixation $^{14}$ and were later quantified by scanning with an automatic computing densitometer (Gelman Instrument Co, Ann Arbor, Michigan, USA). The C3 fragment identified in pancreatitis serum by this technique may be either $\mathrm{C} 3 \mathrm{bi}$ or $\mathrm{C} 3 \mathrm{c}$. We think that it is $\mathrm{C} 3 \mathrm{c}$ because it has the same electrophoretic mobility as the $\mathrm{C} 3 \mathrm{c}$ generated in aged serum and by trypsinisation. We have also identified C3d in pancreatitic serum in concentrations that parallel the breakdown fragment detected by immunofixation. This technique has a sensitivity of $0.02 \mathrm{~g} / 1$ for $\mathrm{C} 3 \mathrm{c}$ and $0.05 \mathrm{~g} / 1$ for factor $\mathrm{B}$ breakdown products.

Standardisation of assays for $\mathrm{C} 3, \mathrm{C} 4$, and $\mathrm{C} 1 \mathrm{INH}$ was performed against Atlantic Antibodies Calibrator. In the absence of available standards, values for factor $\mathrm{I}$ and factor $\mathrm{H}$ were expressed as a percentage of a normal serum pool derived from 20 adults. Normal ranges for these assays are: C3, $0.55-1.20 \mathrm{~g} / \mathrm{l} ; \mathrm{C} 4,0.20-0.50 \mathrm{~g} / \mathrm{l}$; C1INH, 0.15-0.33 $\mathrm{g} / \mathrm{l}$; factor I, 66-146\%, and factor $\mathrm{H}, 56-164 \%$.

\section{Results}

Sequential measurements of complement components are presented in Figs. 1-6 both as concentrations and as the percentage change over the measurement on the day of admission, day 0 . The Table shows the significance of the differences between the levels on days 1 to 4 and day 0 tested by a paired Student's $t$ test.

\section{COMPLEMENT BREAKDOWN PRODUCTS}

C3 breakdown was considered to be significant if C3c levels were greater than $10 \%$ of the total $\mathrm{C} 3$; levels below this may sometimes occur because of faulty blood sampling or prolonged storage of blood before separation. C3 breakdown was seen in 19 of the 26 patients. Breakdown was maximal on day 1 and showed a slight tendency to decrease over the four days (Fig. 1). Factor B breakdown was not encountered in any sample.

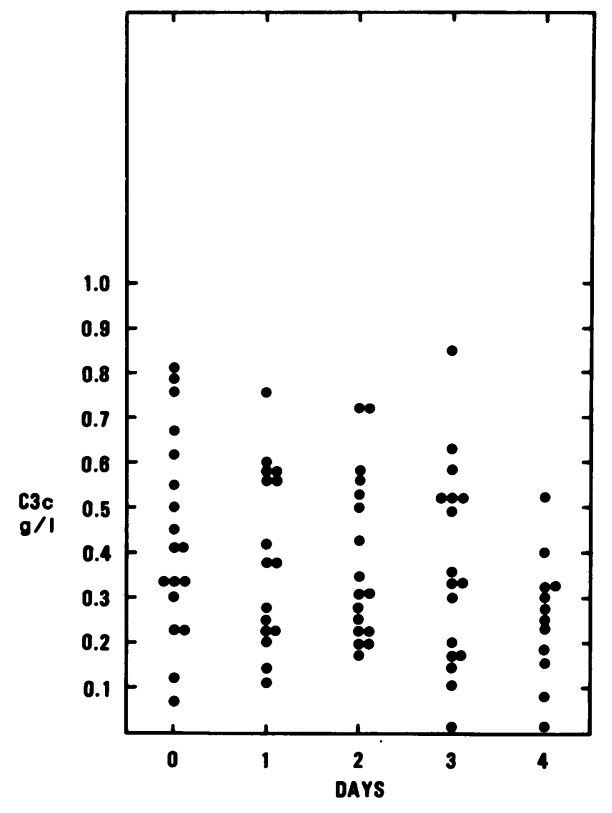

Fig. 1 C3c concentrations on the first four days after admission.

COMPLEMENT COMPONENT LEVELS

Total C3 concentration fell during the first day in those patients with $\mathrm{C} 3$ breakdown products. In the remaining seven, C3 increased on day 3 (Fig. 2, Table). C4 showed a slight tendency to increase over the four days but these changes were not statistically significant (Fig. 3, Table).

\section{COMPLEMENT INHIBITOR LEVELS}

$\mathrm{C} 1 \mathrm{INH}$ and factor $\mathrm{H}$ both increased over the four days of the study. Factor I showed a slight fall followed by an increase (Figs. 4, 5, 6, Table).

\section{RELATIONSHIP OF COMPLEMENT CHANGES TO CLINICAL COURSE}

We were unable to show any relationship between C3 breakdown or changes in other complement components and the clinical severity of the pancreatitis. Profound C3 breakdown occurred in some patients with mild symptoms, while at least one severely shocked patient showed insignificant levels of the breakdown product $\mathrm{C} 3 \mathrm{c}$.

\section{Discussion}

The results confirm the findings of Goldstein $\mathrm{et} \mathrm{al}^{7}$ that $\mathrm{C} 3$ levels fall and $\mathrm{C} 3$ breakdown products are 


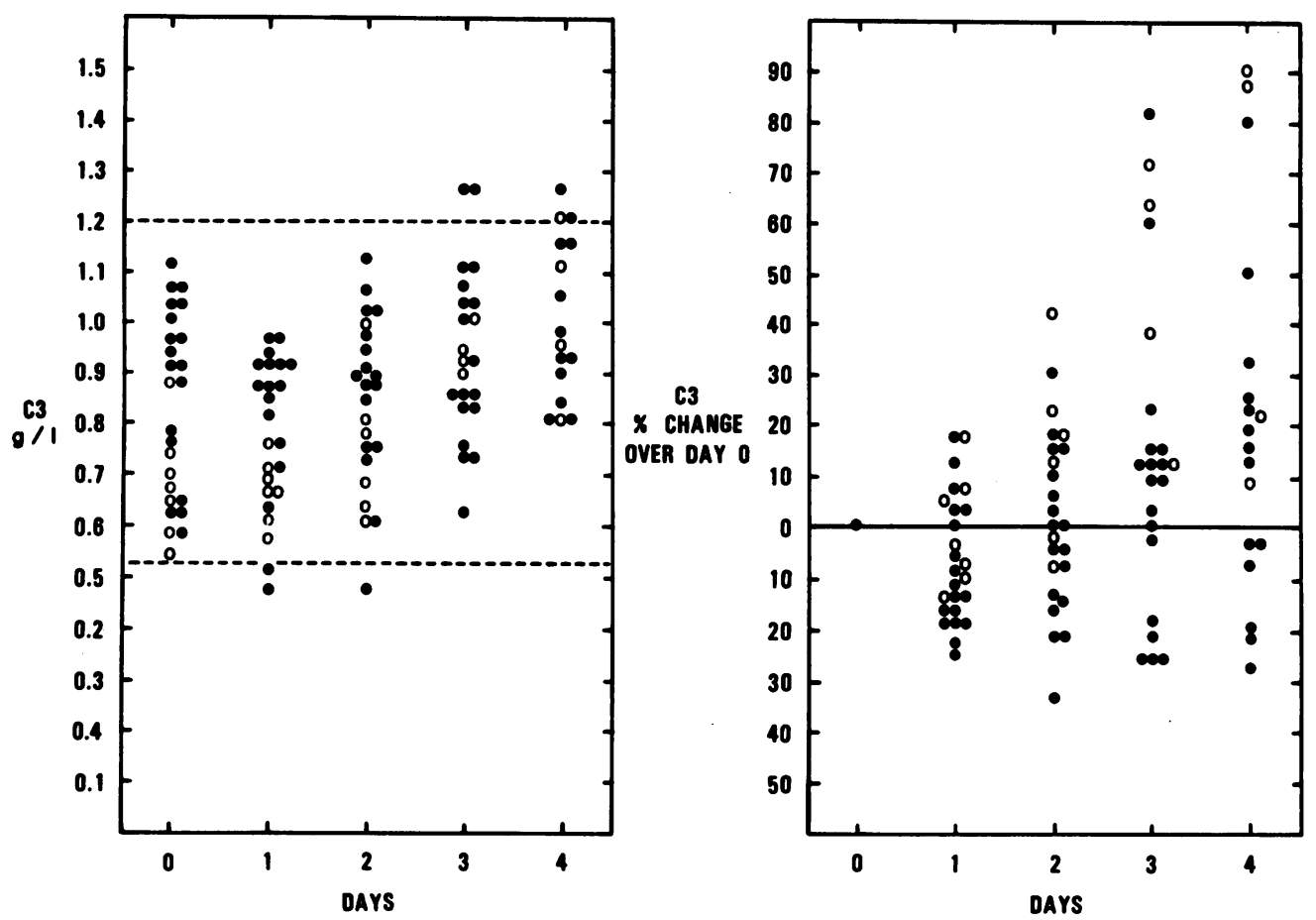

Fig. 2 C3 concentrations and percentage changes over the day of admission (day 0). Normal reference range is shown by interrupted lines. 1 with complement activation. $O$ without complement activation.

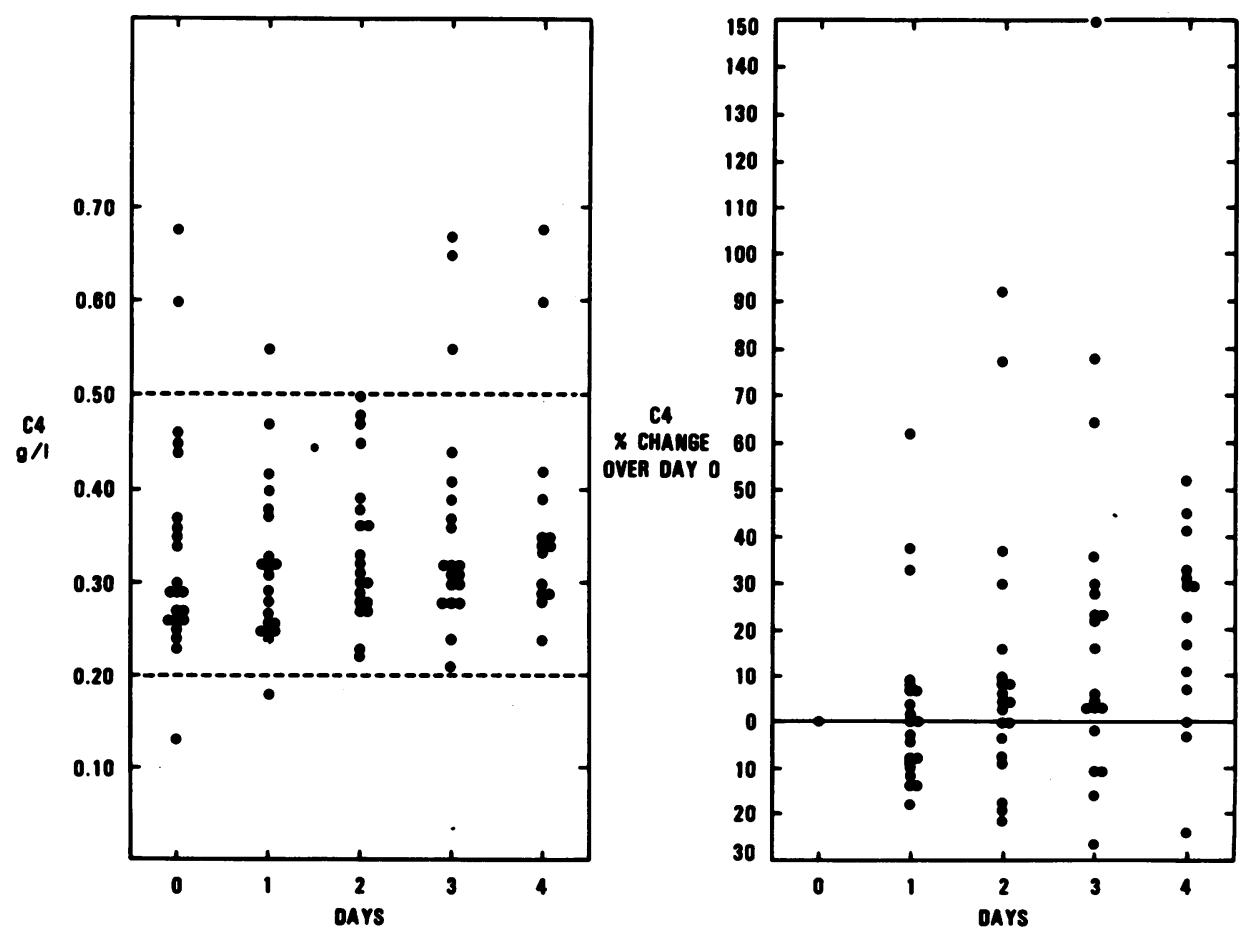

Fig. 3 C4 concentrations and percentage changes over the day of admission (day 0). - - - Normal reference range. 

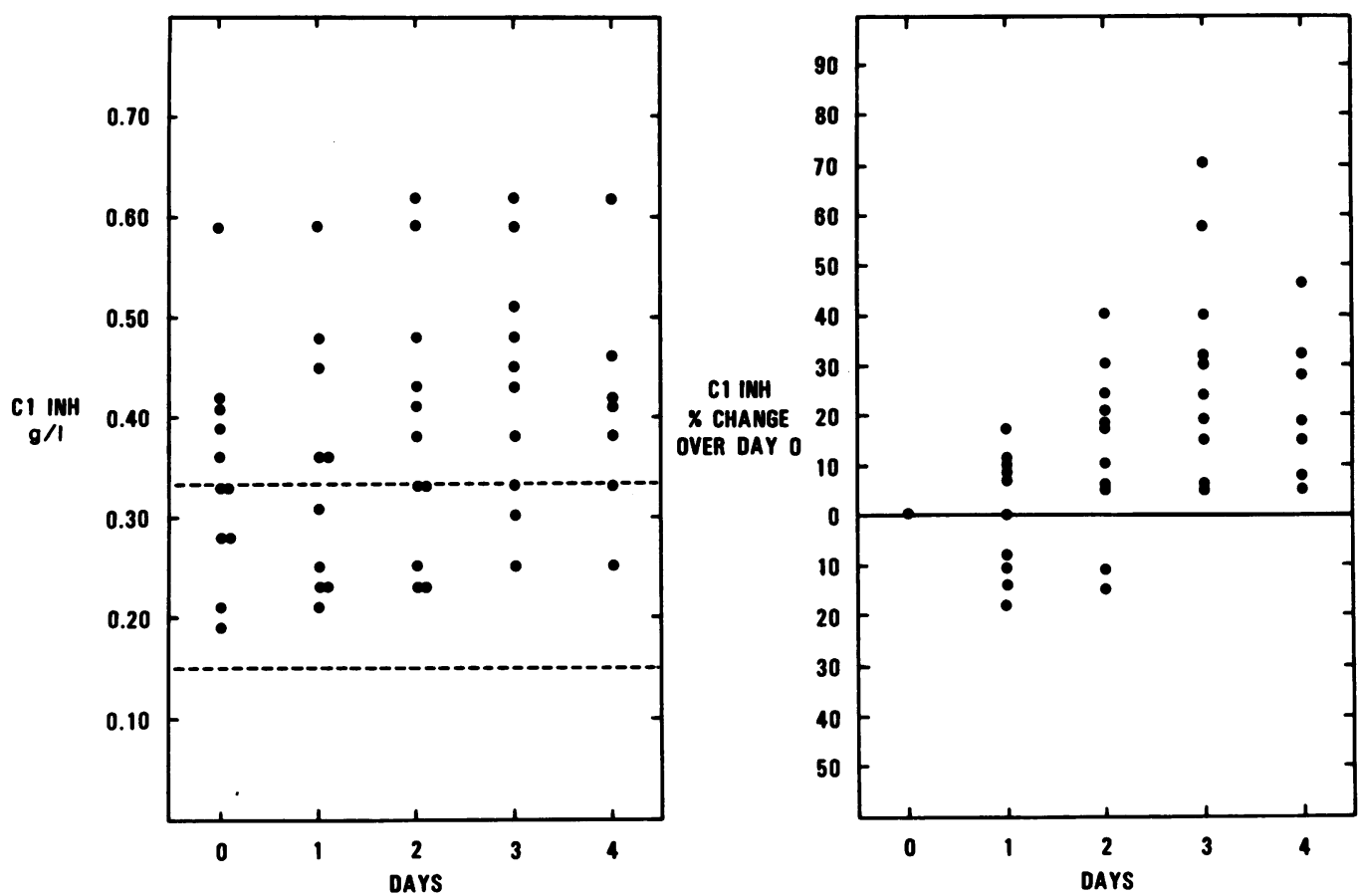

Fig. 4 CIINH concentrations and percentage changes over the day of admission (day 0). - - - Normal reference range.
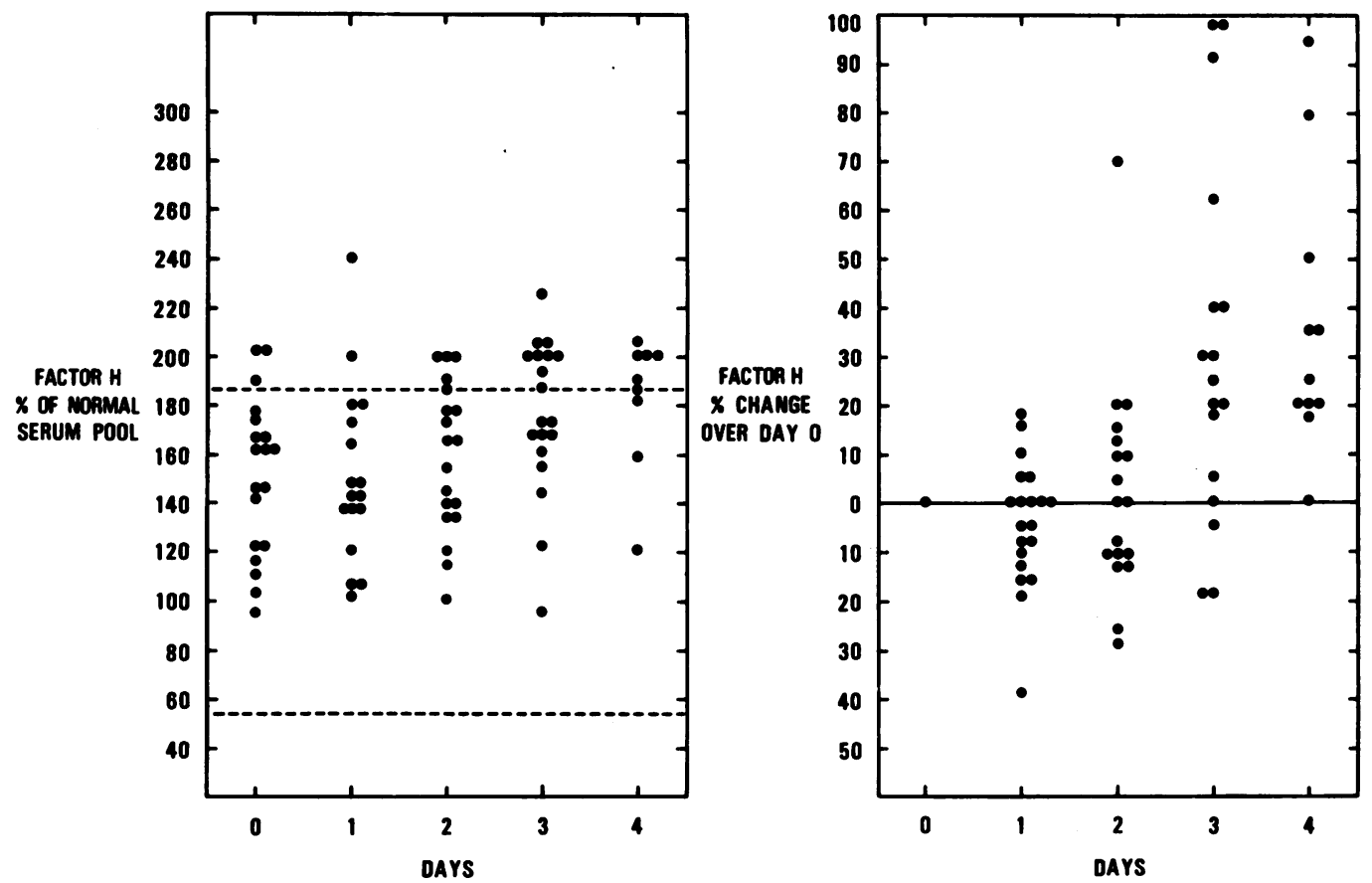

Fig. 5 Factor $H$ concentrations and percentage changes over the day of admission (day 0). - - - Normal reference range. 

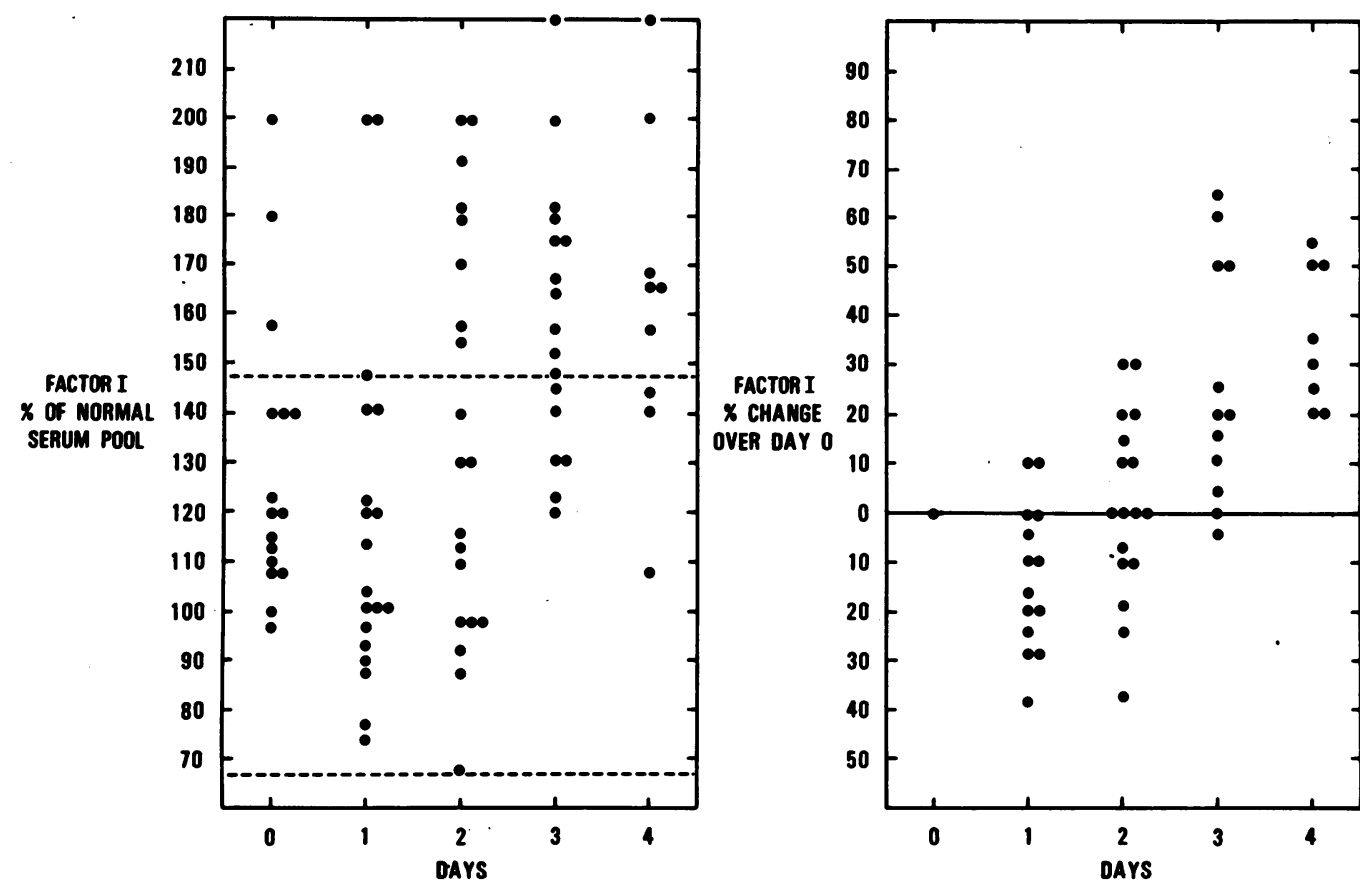

Fig. 6 Factor I concentrations and percentage changes over the day of admission (day 0). - - - Normal reference range.

present in some patients with acute pancreatitis. In contrast we have shown no decrease in $\mathrm{C} 4$ levels and also an absence of factor $B$ breakdown products.

There is good evidence that proteolytic enzymes in particular, trypsin - cleave both $\mathrm{C} 1$ and $\mathrm{C} 3$. $^{3-6}$ The absence of a decrease in $\mathrm{C} 4$ levels in our patients suggests that cleavage of $\mathrm{C} 3$ is not mediated via activation of $\mathrm{C} 1$ but that it may be a direct effect of trypsin. The initial fall and subsequent rise in C3 concentration probably represents complement consumption as a result of breakdown followed by the effects of an acute phase response in which complement levels are known to increase. ${ }^{12}$ This interpretation is supported by the absence of an initial fall in $\mathrm{C} 3$ concentration in those patients who did not have C3 breakdown products in their plasma. The higher overall $\mathrm{C} 3$ levels in those patients with $\mathrm{C} 3$ breakdown suggests a more marked acute phase response in this group particularly on day 0 . There was a tendency for those patients with higher initial C3 levels on day 0 also to have high factor I and factor $\mathrm{H}$ levels. It may thus be that the

Table Mean values $(\bar{x})$ for complement components and significance of difference between values on day 0 and on subsequent days

\begin{tabular}{|c|c|c|c|c|c|c|c|c|c|}
\hline \multirow[b]{3}{*}{ Complement component } & \multicolumn{9}{|c|}{ Days } \\
\hline & \multirow{2}{*}{$\frac{0}{\bar{x}}$} & \multirow{2}{*}{$\frac{1}{\bar{x}}$} & \multirow{2}{*}{$\frac{0-1}{p}$} & \multirow{2}{*}{$\frac{2}{\bar{x}}$} & \multirow{2}{*}{$\frac{0-2}{p}$} & \multirow{2}{*}{$\frac{3}{\bar{x}}$} & \multirow{2}{*}{$\frac{a-3}{p}$} & \multirow{2}{*}{$\frac{4}{\bar{x}}$} & \multirow{2}{*}{$\frac{0-4}{p}$} \\
\hline & & & & & & & & & \\
\hline C3 (with breakdown) & 0.89 & 0.81 & 0.01 & 0.87 & NS & 0.94 & NS & 1.0 & NS \\
\hline C3 (with no breakdown) & 0.69 & 0.67 & NS & 0.75 & $0 \cdot 10$ & 0.91 & 0.005 & 0.99 & NS \\
\hline $\mathrm{C} 4$ & 0.32 & 0.32 & NS & 0.34 & NS & 0.35 & NS & $0 \cdot 37$ & NS \\
\hline CIINH & 0.35 & 0.35 & NS & 0.39 & 0.05 & 0.43 & 0.001 & 0.41 & 0.005 \\
\hline Factor I & 127 & 117 & 0.05 & 135 & NS & 158 & 0.005 & 153 & 0.025 \\
\hline Factor $\mathbf{H}$ & 140 & 147 & NS & 160 & NS & 179 & 0.005 & 180 & 0.025 \\
\hline
\end{tabular}

NS: Not significant. 
inflammatory reaction was more severe in these patients, although this was not apparent clinically. The levels on day 0 are therefore in no way baseline values and reflect the effects of a disease process which has been proceeding for a variable period of time before admission to hospital.

The changes in concentrations of complement inhibitors support the suggestion that trypsin may be responsible for complement breakdown in pancreatitis. C1INH shows a significant increase in the acute phase in all patients regardless of the amount of $\mathrm{C} 3$ breakdown. There is thus no evidence of C1INH consumption as might be suspected if $\mathrm{C} 1$ activation were occurring. Both factor $\mathrm{H}$ and factor I showed a significant acute phase increase over the four days of the study. Factor I, however, showed a significant fall on day 1 suggesting the possibility of consumption by binding to $\mathrm{C} 3 \mathrm{~b}$ and subsequent rapid metabolism. This may occur because of the clearance of complexes from the circulation despite the fact that factor $I$ is not consumed as a result of complement activation in vitro. The lack of a fall of factor $\mathrm{H}$ is interesting in view of the finding of Whaley et $a l^{15}$ who saw a fall in the levels of both factor $\mathrm{I}$ and factor $\mathrm{H}$ in Gram negative endotoxic shock with $\mathrm{C} 3$ activation. Factor I enzymatically inactivates $\mathrm{C} 3 \mathrm{~b}$ to form $\mathrm{C} 3 \mathrm{bi}$. Factor $\mathrm{H}$ binds to $\mathrm{C} 3 \mathrm{~b}$ and potentiates the activity of factor I, but it also dissociates the alternative pathway convertases $\mathrm{C} 3 \mathrm{bBb}$ and $\mathrm{C} 3 \mathrm{bBbP}$ by displacing $\mathrm{Bb}$ from the complexes, thus allowing the conversion of the $\mathrm{C} 3 \mathrm{~b}$. Significant alternative pathway activation with factor $B$ breakdown occurs in Gram negative endotoxic shock possibly consuming factor $\mathrm{H}$ as a result of binding to factor B-containing complexes. The lack of fall in factor $\mathrm{H}$ in pancreatitis may thus be related to the absence of factor $B$ activation.

It has been suggested that complement effector molecules may be responsible for some of the systemic pathological changes occurring in pancreatitis. ${ }^{8}$ Lankisch et al ${ }^{16}$ measuring $\mathrm{C} 3, \mathrm{C} 4$, and total haemolytic complement activity, showed that the majority (24 out of 35 ) of the patients in their study had normal or raised levels. Eight patients who died of haemorrhagic pancreatitis, however, all had generally lowered or declining levels.

We believe that our findings suggest that $\mathrm{C} 3$ breakdown in pancreatitis is due to direct tryptic activation of $\mathrm{C} 3$ with rapid degradation of $\mathrm{C} 3 \mathrm{~b}$ to inactive C3c and C3d and a consequent lack of alternative pathway activation. Furthermore, such measurements appear to be of no clinical value in this condition. It is, however, important to appreciate that conclusions drawn from the measurement of complement component levels are at best tentative in acutely ill patients who may have fluctuating plasma volumes. Turnover studies would be helpful in more clearly elucidating the changes which are occurring.

\section{References}

1 Ohlsson K. Experimental pancreatitis in the dog. Appearances of complexes between proteases and trypsin inhibitors in ascitic fluid, lymph and plasma. Scand J Gastroenterol 1971; 6: 645-52.

2 Ohlsson K, Tegner H. Experimental pancreatitis in the dog. Demonstration of trypsin in ascitic fluid, lymph and plasma. Scand J Gastroenterol 1973; 8: 129-33.

3 Cochrane CG, Muller-Eberhard HJ. The derivation of two distinct anaphylatoxin activities from the third and fifth components of complement. J Exp Med 1968; 275: 267-74.

4 Bokish VA, Muller-Eberhard HJ, Cochrane CG. Isolation of a fragment (C3a) of the third component of human complement containing anaphylatoxin and chemotactic activity and description of an anaphylatoxin inactivator of human serum. J Exp Med 1969; 129: 1109-30.

5 Molenaar JL, Muller MAC, Engelfriet CP, Pondman $\mathrm{KW}$. Changes in antigenic properties of human $\mathrm{C} 3$ upon activation and conversion by trypsin. $J$ Immunol 1974; 112: 1444-51.

6 Fontaine M, Rivat C. A study of the breakdown of the third component of human complement (C3). Ann Immunol 1979; 130c: 349-66.

7 Goldstein IM, Cala D, Radin A, Kaplan HB, Horn J, Ranson J. Evidence of complement catabolism in acute pancreatitis. Am J Med Sci 1979; 275: 267-74.

8 Seelig R, Lankish PG, Koop H, Kaboth U, Winckler $K$, Seelig HP. The serum complement system as initiator and prognostic clue in acute pancreatitis. (Abstract) Irish J Med Sci 1977; 146: Suppl 1. Dublin 1977.

9 Smith Jr WI, Lombardi B, Rabin BS, van Thiel DH, Iammatino RM. C3 and $\alpha_{1}$-antitrypsin in human pancreatitis. (Abstract). Gastroenterology 1977; 72: 1134.

10 Seelig R, Eheman V, Tschahargane C, Seelig HP. The serum complement system - a mediator of acute pancreatitis. Virchows Arch [Path \& Anat] 1975; 365: 193-9.

11 Seelig R, Lankisch PG, Koop H, Winckler K, Kaboth U, Seelig HP. Complement system in sodium taurocholate pancreatitis in the rat. Res Exp Med 1978; 174: 57-65.

12 Whicher JT. The value of complement assays in clinical chemistry. Clin Chem 1978; 24: 7-22.

13 Laurell C-B. Antigen-antibody crossed electrophoresis. Ann Biochem 1965; 10: 358-61.

14 Whicher JT, Higginson J, Riches PG, Radford S. 
Clinical applications of immunofixation: detection and quantitation of complement activation. $J$ Clin Pathol 1980; 33: 781-5.

15 Whaley K, Yee Khong R, McCartney AC, Ledingham IMcA. Complementa activation and its control in gram-negative endotoxic shock. J Clin Lab Immunol 1972; 2: 117-24.

16 Lankisch PG, Koop H, Kaboth U. Serum complement factors in human acute pancreatitis. HepatoGastroenterol 1981; 28: 261. 